\title{
The Establishment of an e-Learning System Based on SDT
}

\author{
http://dx.doi.org/10.3991/ijet.v9i4.3704 \\ Mihyang Bang, Kwangyun Wohn and Chungkon Shi \\ Kaist, Daejeon, Republic of Korea
}

\begin{abstract}
This study established an elementary-school English e-learning system on the basis of theory-based motivation strategies, and verified the effectiveness of the motivation strate\#gies through educational practice and the applicability of traditional motivation theories in e-learning environments. Six motivation strategies were deducted, two from each of the three psychological needs (Autonomy, Competence, Relatedness) presupposed as preconditions that increase human motivation based on the SelfDetermination Theory. Next, the e-learning system intended to increase intrinsic motivation for English learning was established based on the motivation strategies. Then, this system was used for year-long educational practice in 115 private educational institutes nationwide. Finally, a survey was conducted with 2,300 students to determine whether the e-learning system applying the motivation strategies satisfied the three psychological needs of elementary-school English learners, and whether it improved intrinsic motivation for English studies. Moreover, this study analysed the correlation among motivation strategies, three psychological needs, and five motivation groups. The results revealed that the motivation strategies applied to the e-learning system had a significant influence on the three psychological needs, and those needs had a significant influence on the five motivation groups. This proved the effectiveness of motivation strategies applied to the e-learning system. It was found that SDT, the traditional motivation theory that has been applied to face-to-face classes, is also effective in the e-learning environment. Finally, even in the e-learning environment focusing on individual learning, learners were found to value relationships with others, in addition to competence, which has been studied relatively often in the past. The significance of this study is that it established a theory-based elearning system and that it is an empirical study applying motivation theories from face-to-face classes to the elearning environment through educational practice.
\end{abstract}

Index Terms-computer-mediated communication, distance education, user interface, teaching strategies

\section{INTRODUCTION}

Unlike face-to-face classes, an e-learning environment possesses characteristics such as flexibility, accessibility, and communication through the mediation of computers (Carr, 2000). Therefore, there is a need for research that empirically verifies the applicability of traditional motivation theory to this relatively new learning environment (Chen \& Jang, 2007). Although some studies have applied motivation strategies to e-learning (Carr 2000), most merely highlight high attrition rates (which are a negative index for motivation) and the resultant pressurization. Only a small number of studies empirically verify whether motivation strategies are applicable to the e-learning environment, and very few have targeted children. Research questions based on the aforementioned issues are as follows:

1. How can one establish an e-learning system that applies theory-based motivation strategies?

2. Did the new e-learning system increase learners' intrinsic motivation?

3. If learners' intrinsic motivation did increase, how does it correlate with other research variables?

To answer these questions, this study implements SelfDetermination Theory (SDT), a motivation theory developed by Deci and Ryan $(1985 ; 2000)$. SDT has traditionally been applied to research concerning foreign-language learners' motivation, and therefore is highly appropriate for a comparative study between face-to-face instruction and e-learning.

SDT proposes that increased human motivation is based on three psychological needs: autonomy, competence, and relatedness. This study begins by deducting a total of six motivation strategies, two from each psychological need, as preconditions for increased human motivation. Based on the motivation strategies derived from the theory, an elementary-school English e-learning system named English Buddy (EB) was developed. This study implemented an educational practice in 115 different private institutes (Prunet institute) throughout Korea for one year; 2,300 students were later surveyed to verify the effectiveness of motivation strategies and the applicability of traditional motivation theories to an e-learning environment.

\section{SELF-DETERMINATION THEORY RELATED TO FOREIGN LANGUAGE STUDIES}

Self-determination theory addresses factors that either facilitate or undermine motivation, both intrinsic and extrinsic. SDT asserts that three types of psychological needs are prerequisites for increased human motivation. The first is a need for autonomy, and autonomy within SDT involves a sense of volition or willingness to complete a task (Deci \& Ryan 1980; Ryan \& Deci 2000). When activities are done for interest or personal value, perceived autonomy is high. The second requirement is competence, which can be defined as a need for challenge and feelings of effectance (White 1959; Deci 1975). SDT proposes that opportunities to acquire new skills or abilities, to be optimally challenged, or to receive positive feedback enhance the experience of competence. The third need is for relatedness, in which a learner desires to be closely related with the people and society that surrounds them, and to develop an amicable solidarity with others.

The causal relation between these three needs and intrinsic motivation is not only supported by psychologists such as Deci, but also in the field of foreign language 
PAPER

THE ESTABLISHMENT OF AN E-LEARNING SYSTEM BASED ON SDT

studies (Noels et al. 2000; Noels 2001). In other words, learning activities that satisfy the three aforementioned psychological needs are an effective means to increase learners' motivation.

Moreover, SDT does not deal with intrinsic and extrinsic motivation oppositively, but categorizes the five motivations of amotivation, external regulation, introjected regulation, identified regulation, and intrinsic motivation in a continuum according to the degree of selfdetermination shown in Figure 1 (Dörnyei 1994a). Noels et al. (2000) discovered that this continuum is applicable to the field of foreign language studies.

\begin{tabular}{|c|c|c|c|}
\hline $\begin{array}{l}\text { Type of } \\
\text { Amotivation }\end{array}$ & Amotivation & Extrinsic Motivation & $\begin{array}{l}\text { Intrinsic } \\
\text { Motivation }\end{array}$ \\
\hline $\begin{array}{l}\text { Type of } \\
\text { Regulation }\end{array}$ & $\begin{array}{l}\text { Non } \\
\text { regulation }\end{array}$ & $\begin{array}{l}\text { External Introjected Identified } \\
\text { Regulation Regulation Regulation }\end{array}$ & $\begin{array}{l}\text { Intrinsic } \\
\text { Regulation }\end{array}$ \\
\hline $\begin{array}{l}\text { Quality of } \\
\text { Behavior }\end{array}$ & $\begin{array}{c}\text { Non self } \\
\text {-determined }\end{array}$ & & $\begin{array}{c}\text { self } \\
\text {-determined }\end{array}$ \\
\hline
\end{tabular}

Figure 1. Continuum of Motivation Based on SDT

\section{RESEARCH MODEL}

Through theoretical analysis, this study deducts a total of six motivation strategies, two for each of the three needs.

Fig 2 shows the EB system's [accessible at www.englishbuddy.kr] conceptual diagram applying the motivation strategies. Figure 3 shows the verification of the research model. The research hypothesis is as follows:

The six motivation strategies applied to the EB System have a significant influence on the three psychological needs of learners, and fulfilled needs have a significant influence on the five motivation groups, resulting in learners' increased intrinsic motivation to study English.

The EB system incorporates a website to access content, a Learning Management System (LMS) to record students progress and achievements, and interactive flash content. As shown in Figure 5, learners can access the system via a web browser that has the Adobe Flash plug-in installed. The student's progress is monitored by the LMS, and the learner can access class syllabi, grades, personal details, and past test results (Figure 6). Teachers have access to an administrative page (Figure 6) where he or she can evaluate a learner's performance and grade them appropriately.

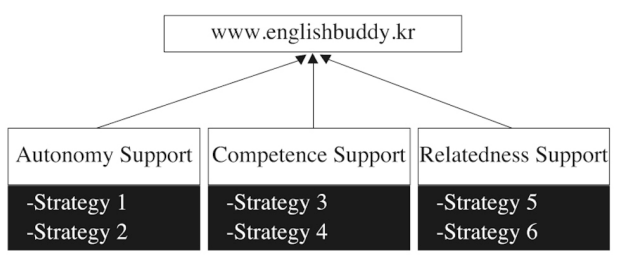

Figure 2. EB System Conceptual Diagram

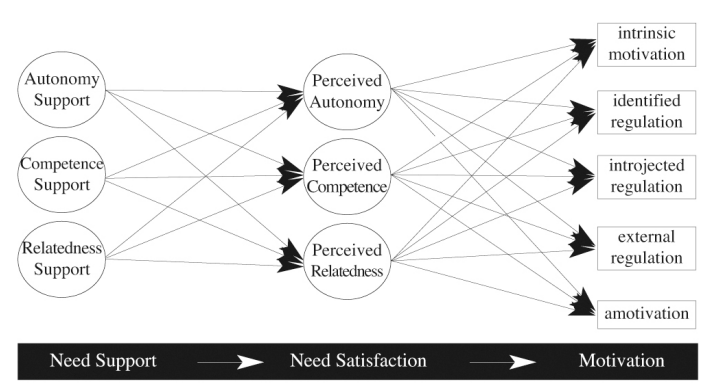

Figure 3. Research Mimic Diagram
A. EB System and its Application

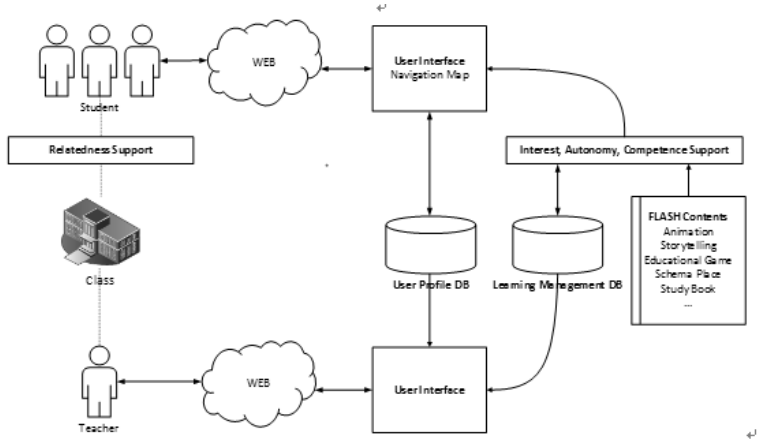

Figure 4. EB System(www.englishbuddy.kr) Outline
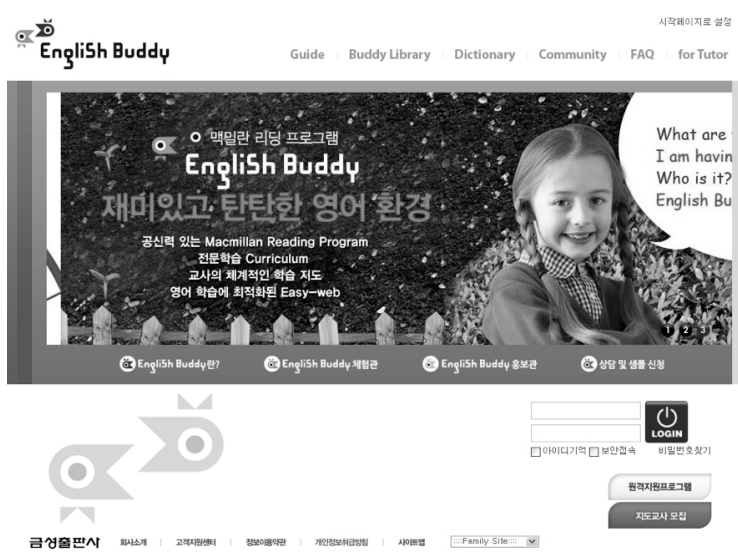

Figure 5. EB System Log-in Page
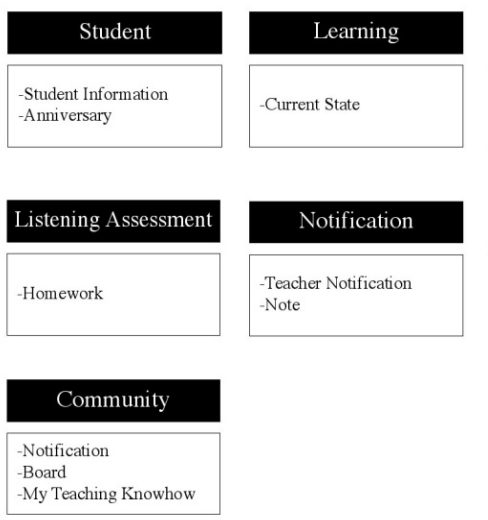

Evaluation

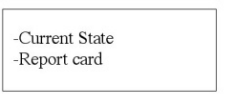

Teaching Materials

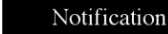

Teacher Notification

-Note

Multimedia Materias -Activity Materials

(a) Teacher Site Map
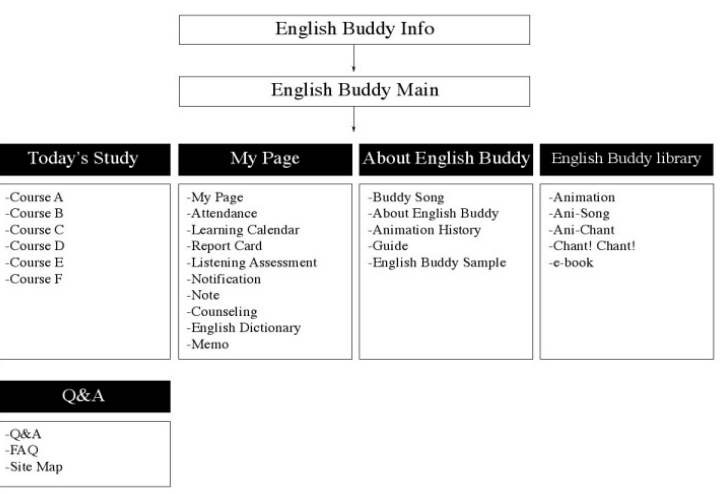

(b) Student Site Map

Figure 6. EB System(www.englishbuddy.kr) Site Map 
B. Motivation Strategies Applied to the EB System

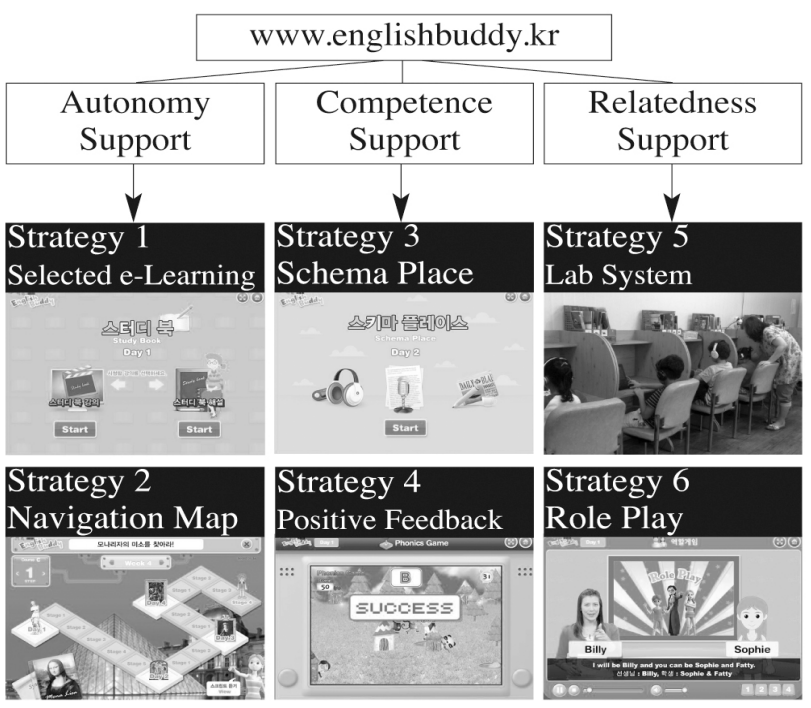

Figure 7. Research Mimic Diagram

Learning Navigation and selected e-learning lectures provide Autonomy Support, while Schema Place and 16 feedback managers provide immediate and positive reinforcement for Competence Support. Offline lab activities and role playing games are used as Relatedness Support strategies.

\section{1) Strategies for Autonomy Support}

\section{a) Learning Navigation Support}

A navigation problem, in which learners fail to choose an appropriate path, often occurs in the e-learning environment (Hasegawa, 06). Thus, this study provided learning navigation by organizing an adaptive environment which can be controlled by learners. Of course, it limits learner autonomy because learning directions are restricted by developers in advance. Therefore, this study programme is conducted three times a week using a navigation map. It also ensured that learners had the authority to control the contents and amount of education, as well as the learning processes.

\section{b) Selective e-Learning Lecture Support}

The e-learning lecture design and learner autonomy allowed learners to listen to the entire lecture, as well as explanations thereof, and ask questions selectively. A video lecture (VOD) method was used for total listening. Selective listening convinced learners that their learning processes were smooth and effective, by enabling them to proactively make choices beyond a passive frame, which was regarded as the greatest weakness of VOD.

2) Strategies for Competence Support

\section{a) Schema Place}

A 'Schema' learning method improves learning effects by diagnosing, extracting, and activating his or her Schema, while the teacher and learner exchange background knowledge through mutual questions and answers. Its importance is steadily increasing with the development of an interactive e-learning system.

This study designed the 'Schema Place' (Fig 8) based on the interaction of three factors - conceptual abilities, background, and process strategies - which are necessary in an EFL environment such as Korea.

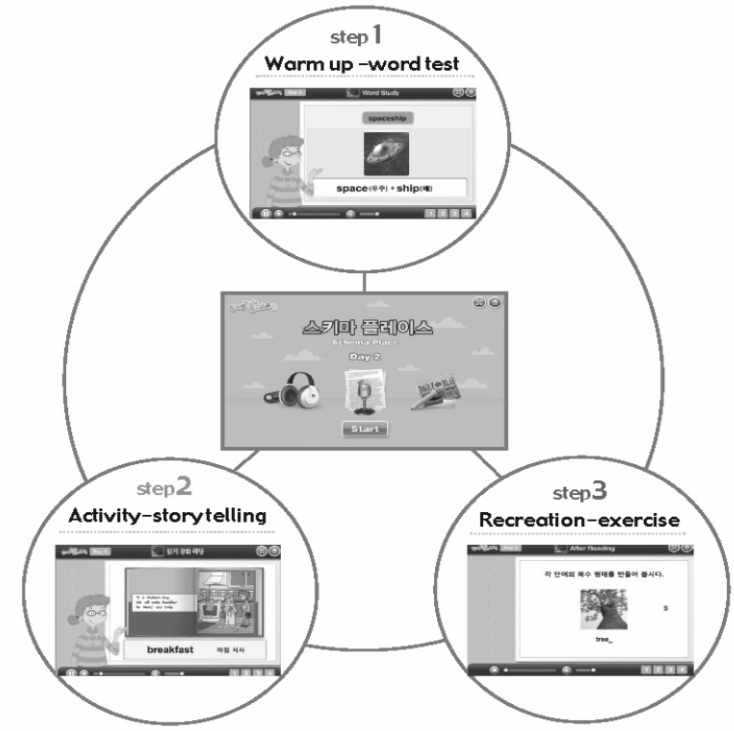

Figure 8. Schema Place

\section{b) Immediate and Positive Feedback on Learning} Activities

Sixteen managers exclusively responsible for system and feedback support were arranged in the EB system, to provide immediate and positive feedback on all learning activities. Moreover, a question activity and a message function were designed to continuously promote learner participation.

\section{3) Strategies for Relatedness Support}

\section{a) Lab System Support}

The EB system is a method which requires learners to attend a private educational institute and study in a lab three times a week. They are supposed to study using the EB system for 60 minutes each time, managed by teachers of private institutes. A lab-management model is demonstrated in Fig 9.

\begin{tabular}{|c|c|c|c|}
\hline \multirow[t]{2}{*}{1} & \multirow[t]{2}{*}{$\begin{array}{l}\text { Attendance and } \\
\text { sitting }\end{array}$} & Teacher & $\begin{array}{c}\text { Check attendance (LMS } \\
\text { system) }\end{array}$ \\
\hline & & Student & $\begin{array}{c}\text { Begin studying after } \\
\text { logging in }\end{array}$ \\
\hline \multirow[t]{2}{*}{2} & \multirow[t]{2}{*}{$\begin{array}{l}\text { Self-directed } \\
\text { learning }\end{array}$} & Student & $\begin{array}{c}\text { Finish studying a set } \\
\text { amount of learning con- } \\
\text { tents per day for } 60 \\
\text { minutes }\end{array}$ \\
\hline & & Teacher & $\begin{array}{l}\text { Observe and manage } \\
\text { learners' learning atti- } \\
\text { tudes }\end{array}$ \\
\hline \multirow{4}{*}{3} & \multirow{4}{*}{$\begin{array}{l}\text { Learning man- } \\
\text { agement }\end{array}$} & & \\
\hline & & Teacher & $\begin{array}{l}\text { Assess learners' learning } \\
\text { results through questions }\end{array}$ \\
\hline & & Student & $\begin{array}{l}\text { Ask questions on con- } \\
\text { tents of interest }\end{array}$ \\
\hline & & Teacher & $\begin{array}{c}\text { Record learners' learning } \\
\text { contents, attitudes, and } \\
\text { awareness }\end{array}$ \\
\hline
\end{tabular}

\begin{tabular}{|l|l|l|l|}
\hline 4 & Returning home & Student & Log out \\
\cline { 3 - 4 } & Teacher & $\begin{array}{c}\text { Record the time when } \\
\text { learners return home } \\
\text { (LMS system) }\end{array}$ \\
\hline
\end{tabular}

Figure 9. A Lab-Management Model 


\section{b) Role Play}

Students conducted a role play based on the conversation of characters in the EB programme. It encouraged learners to have a sense of solidarity in e-learning through an activity in which they acted as certain characters, and exchanged conversation on the contents they studied with other characters, based on their roles.

\section{Educational Practice}

Educational practice was conducted at 115 private institutions nationwide for one year beginning in July 2010 (Figure 10). More than 7,000 students from grades one and six used the EB system 60 minutes a day, three times a week from the institutes' teacher-managed computer labs.

\section{RESEARCH}

Investigations one, two, and three were conducted in response to research questions two and three. The three investigation questions were:

1. Did the EB system fulfil learners' three psychological needs?

2. Did fulfilment of the three psychological needs result in increased intrinsic motivation?

3. How do motivation strategies, the three psychological needs, and the five motivation groups correlate?

\section{Methods}

Korean students in private institutes can choose between two curriculums: an integrated program that covers all subjects collectively, or an individualized program where subjects such as English and mathematics are studied separately. The 115 institutes (Prunet institute) investigated for this study offer both programs. Each school's integrated program is offered in the form of face-to-face classes that meet for 90 minutes twice a week.

Accordingly, this study surveyed 900 students from the group mentioned above, and 1,400 students from the same grade, with the latter group using the EB system for 60 minutes three times a week. The survey lasted a month from 1- 30 July 2011.

To fulfill the investigation's objective, the following two survey methods were applied.

\section{A. Assessment of the Three Psychological Needs}

Referring to prior studies that applied SDT to interpersonal relations (Deci et al. 2001; Ryan \& Deci 2000; Hiromori 2006), the questionnaire contained 11 questions that determined whether the three variables (autonomy, competence, and relatedness) reflected the researcher's intentions and their relevance to e-learning.

\section{B. Assessment of Intrinsic Motivation in English Studies}

For the assessment of intrinsic motivation, this study referred to previous SDT-based studies (Noels et al. 2000; Vallerand 1992; Hiromori 2006). The assessment consisted of 18 items across five motivation groups to determine whether they reflected the researcher's intentions and their relevance to e-learning. A five-point Likert scale was used for assessment, with 5 and 1 indicating strong agreement and disagreement respectively.

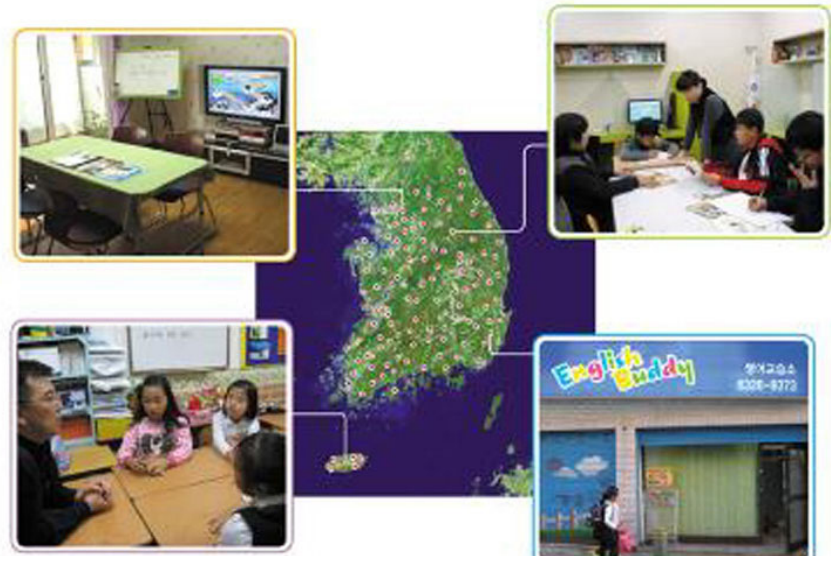

Figure 10. Educational Practice EB System

\section{DATA ANALYSIS}

\section{A. Method of Analysis}

For Investigation One, comparative analysis was performed between two groups according to the periodical gap; for Investigation Two, comparative analysis was conducted among the three groups, including the two aforementioned groups and an additional one that did not utilize the EB system. 2,300 questionnaires were distributed in total, of which 2,087 were returned. The three groups were profiled according to the following criteria:

1. 792 out of 1,400 third graders who used the EB system for one to six months, 60 minutes a day, three times a week

2. 473 out of 1,400 third graders who used the EB system for seven to twelve months, 60 minutes a day, three times a week

3. 822 out of 900 third graders who studied English face-to-face 90 minutes a day, twice a week

To compare the mean afterward, all questions were grouped into categories, and the questions' consistency was verified using the Cronbach alpha coefficient of reliability analysis. The results are as follows: autonomy strategies $=.855$, competence strategies $=.879$, relatedness strategies $=.881$, autonomy $=.700$, competence $=.620$, relatedness $=.864$, intrinsic motivation $=.890$, identified regulation $=.807$, introjected regulation $=.638$, external regulation $=.718$, amotivation $=.859$. The Cronbach alpha coefficient was generally 0.7 or higher, adequately fulfilling concept reliability.

\section{B. Analysis Results and Considerations}

\section{1) Investigation One Analysis Results}

First, mean difference analysis was applied to Group A and B to ensure their quality. This was completed prior to applying Levene's equal variance test, and subsequently verified both groups' identical quality.

Results determining whether motivation strategies fulfilled learners' three psychological needs were analysed using an independent sample t-test for all items, indicating a statistically significant difference $(99.9 \%)$ in the confidence level (Table 1). Analysis to determine Study Period (Group) effects exhibited a statistically significant difference of $99.9 \%$ following an independent sample t-test. 
TABLE I.

MEAN, STANDARD DEVIATION, INDEPENDENT T-TEST RESUlt OF THE THREE PSYCHOLOGICAL NEEDS

\begin{tabular}{|c|c|c|c|c|}
\hline & \multicolumn{2}{|c|}{ Study Period (Group) } & \multirow{2}{*}{$\boldsymbol{t}$} & $\begin{array}{c}\text { Significance } \\
\text { Probability }\end{array}$ \\
\cline { 2 - 4 } & Group $\boldsymbol{A}$ & Group B & & $0.000^{* * *}$ \\
\hline Autonomy & $3.27 \pm 0.82$ & $3.56 \pm 0.78$ & -6.224 & $0.000^{* * *}$ \\
\hline Competence & $3.27 \pm 0.78$ & $3.55 \pm 0.77$ & -6.327 & $0.000^{* * *}$ \\
\hline Relatedness & $3.60 \pm 0.91$ & $3.90 \pm 0.80$ & -6.012 & \multicolumn{2}{|c}{} \\
\hline$* * * \mathrm{p}<0.001$ & \multicolumn{4}{|l}{}
\end{tabular}

Considering that each mean had a value between three and four, it was determined that motivation strategies fulfilled all three psychological requirements, and that differences between the two groups were evident. Furthermore, the fulfillment of each psychological need was higher for long-term studies than when compared to short-term studies. Specifically, learning period exhibited a great effect (mean difference $=0.30$ ) on relatedness. Autonomy and competence revealed that some items were not significantly different, and that overall, the long-term students displayed greater needs than their counterparts.

\section{2) Investigation Two Analysis Results}

Prior to analysing the differences between groups, a homogeneity of variance test was conducted to verify the likeness of the experimental and control groups. The results indicated that they were homogeneous, selecting a null hypothesis $(\mathrm{p}>.05)$.

After verifying group homogeneity, a one-way Analysis of Variance (ANOVA) test was conducted to verify the mean difference among groups $\mathrm{A}, \mathrm{B}$, and $\mathrm{C}$. The mean of each group exhibited a clear difeference, which was mirrored by the statistical test result.

Analysing the five motivation groups produced a pvalue according to $F$ statistics below 0.001 , verifying the validity of the model. Group classification from the posthoc analysis placed groups $\mathrm{A}, \mathrm{B}$, and $\mathrm{C}$ into different categories, as shown in Table 2. Groups A and B, who both used the EB system, displayed higher motivation than Group C $(\mathrm{a}, \mathrm{b}>\mathrm{c})$. Furthermore, Group B, who used the EB system for the longest duration, displayed higher motivation than Group A $(\mathrm{a}<\mathrm{b})$.

\section{3) Investigation Three Analysis Results}

The correlation of variables was analysed before analysing the correlation among variables through the structural equation analysis; as a result (Table 3), the correlations among motivation strategies, psychological needs, and motivation groups were relatively high.

Next, an analysis was performed according to the structural equation model to determine the influential relation among motivation strategies, psychological needs, and motivation groups (Table 4). After performing confirmatory factor tests to verify concept validity, as specified by the structural equation analysis, the goodness of fit was $\mathrm{GFI}=.874$, CFI $=.921$, TLI $=.912$, and $\mathrm{RMSEA}=.048$, with an RMSEA quotient of 0.05 or lower. These results indicate that the research model's validity is strong. Research variables were formed based on the results of confirmatory factor analysis; hypothesis testing was then carried out to measure the causal relation among research variables. Analysis of the research hypothesis revealed that the structural equation model's goodness of fit was GFI $=.825$, $\mathrm{CFI}=.88$, TLI $=.868$, RMSEA $=.058$ with an RMSEA quotient of 0.08 or lower. This outcome verifies the research
TABLE II.

MEAN, StANDARd DEVIATION, ANOVA REsult For the Five TyPes OF MOTIVATION

\begin{tabular}{|c|l|l|l|l|l|c|}
\hline & $\begin{array}{c}\boldsymbol{G r o u p} \\
\boldsymbol{A a}\end{array}$ & $\begin{array}{c}\text { Group } \\
\boldsymbol{B b}\end{array}$ & $\begin{array}{c}\text { Group } \\
\boldsymbol{C} \boldsymbol{c}\end{array}$ & $\boldsymbol{T o t a l}$ & $\boldsymbol{F}$ & $\begin{array}{c}\text { Sig- } \\
\begin{array}{c}\text { nifi- } \\
\text { cance } \\
\text { Prob- } \\
\text { ability }\end{array}\end{array}$ \\
\hline $\begin{array}{c}\text { Intrinsic } \\
\text { motiva- } \\
\text { tion }\end{array}$ & $\begin{array}{l}3.42 \pm 0 . \\
89\end{array}$ & $\begin{array}{l}3.71 \pm 0 . \\
95\end{array}$ & $\begin{array}{l}2.89 \pm 0 . \\
91\end{array}$ & $\begin{array}{l}3.28 \\
\pm 0.9 \\
7\end{array}$ & $\begin{array}{l}137 . \\
395\end{array}$ & $\begin{array}{c}0.000 \\
* * *\end{array}$ \\
\hline $\begin{array}{c}\text { Identified } \\
\text { regulation }\end{array}$ & $\begin{array}{l}3.80 \pm 0 . \\
79\end{array}$ & $\begin{array}{l}4.16 \pm 0 \\
.76\end{array}$ & $\begin{array}{l}3.46 \pm 0 . \\
87\end{array}$ & $\begin{array}{l}3.75 \\
\pm 0.8 \\
6\end{array}$ & $\begin{array}{l}115 . \\
072\end{array}$ & $\begin{array}{c}0.000 \\
* * *\end{array}$ \\
\hline $\begin{array}{c}\text { Introject- } \\
\text { ed regula- } \\
\text { tion }\end{array}$ & $\begin{array}{l}3.31 \pm 0 . \\
83\end{array}$ & $\begin{array}{l}.8 .74 \pm 0 \\
.82\end{array}$ & $\begin{array}{l}2.95 \pm 0 . \\
80\end{array}$ & $\begin{array}{l}3.26 \\
\pm 0.8 \\
7\end{array}$ & $\begin{array}{l}142 . \\
625\end{array}$ & $\begin{array}{c}0.000 \\
* * *\end{array}$ \\
\hline $\begin{array}{c}\text { External } \\
\text { regulation }\end{array}$ & $\begin{array}{l}3.61 \pm 0 . \\
90\end{array}$ & $\begin{array}{l}.83 \\
.83\end{array}$ & $\begin{array}{l}3.26 \pm 0 . \\
90\end{array}$ & $\begin{array}{l}3.55 \\
\pm 0.9 \\
2\end{array}$ & $\begin{array}{l}102 . \\
218\end{array}$ & $\begin{array}{l}0.000 \\
* * *\end{array}$ \\
\hline $\begin{array}{c}\text { Amotiva- } \\
\text { tion }\end{array}$ & $\begin{array}{l}3.69 \pm 0 . \\
93\end{array}$ & $\begin{array}{l}.9 .98 \pm 0 \\
.90\end{array}$ & $\begin{array}{l}3.49 \pm 0 . \\
95\end{array}$ & $\begin{array}{l}3.68 \\
\pm 0.9 \\
5\end{array}$ & $\begin{array}{l}41.2 \\
23\end{array}$ & $\begin{array}{c}0.000 \\
* * *\end{array}$ \\
\hline
\end{tabular}

TABLE III.

PEARSON CORRELATION ANALYSIS

\begin{tabular}{|c|c|c|c|c|c|c|c|c|c|c|c|}
\hline & 1 & 2 & 3 & 4 & 5 & 6 & 7 & 8 & 9 & 10 & 11 \\
\hline 1 & 1 & & & & & & & & & & \\
\hline 2 & $\begin{array}{l}.6 \\
09 \\
(* \\
*) \\
\end{array}$ & 1 & & & & & & & & & \\
\hline 3 & $\begin{array}{l}.6 \\
11 \\
(* \\
*) \\
\end{array}$ & $\begin{array}{l}.6 \\
23 \\
(* \\
*) \\
\end{array}$ & 1 & & & & & & & & \\
\hline 4 & $\begin{array}{l}.5 \\
67 \\
(* \\
*) \\
\end{array}$ & $\begin{array}{l}.6 \\
12 \\
(* \\
*) \\
\end{array}$ & $\begin{array}{l}.5 \\
88 \\
(* \\
*) \\
\end{array}$ & 1 & & & & & & & \\
\hline 5 & $\begin{array}{l}.5 \\
47 \\
(* \\
*)\end{array}$ & $\begin{array}{l}.5 \\
76 \\
(* \\
*)\end{array}$ & $\begin{array}{l}.5 \\
35 \\
(* \\
*)\end{array}$ & $\begin{array}{l}.6 \\
31 \\
(* \\
*)\end{array}$ & 1 & & & & & & \\
\hline 6 & $\begin{array}{l}.5 \\
64 \\
(* \\
*)\end{array}$ & $\begin{array}{l}.6 \\
64 \\
(* \\
*) \\
\end{array}$ & $\begin{array}{l}.5 \\
74 \\
(* \\
*)\end{array}$ & $\begin{array}{l}.6 \\
70 \\
(* \\
*)\end{array}$ & $\begin{array}{l}.5 \\
87 \\
(* \\
*)\end{array}$ & 1 & & & & & \\
\hline 7 & $\begin{array}{l}.4 \\
07 \\
(* \\
*)\end{array}$ & $\begin{array}{l}.4 \\
79 \\
(* \\
*) \\
\end{array}$ & $\begin{array}{l}.4 \\
64 \\
(* \\
*)\end{array}$ & $\begin{array}{l}.4 \\
95 \\
(* \\
*)\end{array}$ & $\begin{array}{l}.3 \\
60 \\
(* \\
*)\end{array}$ & $\begin{array}{l}.6 \\
14 \\
(* \\
*)\end{array}$ & 1 & & & & \\
\hline 8 & $\begin{array}{l}3 \\
75 \\
(* \\
*) \\
\end{array}$ & $\begin{array}{l}.4 \\
18 \\
(* \\
*) \\
\end{array}$ & $\begin{array}{l}3 \\
46 \\
(* \\
*)\end{array}$ & $\begin{array}{l}.3 \\
58 \\
(* \\
*)\end{array}$ & $\begin{array}{l}.3 \\
59 \\
(* \\
*)\end{array}$ & $\begin{array}{l}.5 \\
17 \\
(* \\
*)\end{array}$ & $\begin{array}{l}.5 \\
89 \\
(* \\
*)\end{array}$ & 1 & & & \\
\hline 9 & $\begin{array}{l}.3 \\
89 \\
(* \\
*) \\
\end{array}$ & $\begin{array}{l}.4 \\
25 \\
(* \\
*) \\
\end{array}$ & $\begin{array}{l}.4 \\
01 \\
(* \\
*) \\
\end{array}$ & $\begin{array}{l}.3 \\
37 \\
(* \\
*) \\
\end{array}$ & $\begin{array}{l}.3 \\
59 \\
(* \\
*) \\
\end{array}$ & $\begin{array}{l}.4 \\
18 \\
(* \\
*) \\
\end{array}$ & $\begin{array}{l}.4 \\
60 \\
(* \\
*) \\
\end{array}$ & $\begin{array}{l}.5 \\
83 \\
(* \\
*) \\
\end{array}$ & 1 & & \\
\hline 10 & $\begin{array}{l}3 \\
22 \\
(* \\
*) \\
\end{array}$ & $\begin{array}{l}3 \\
74 \\
(* \\
*) \\
\end{array}$ & $\begin{array}{l}.3 \\
27 \\
(* \\
*) \\
\end{array}$ & $\begin{array}{l}.2 \\
67 \\
(* \\
*) \\
\end{array}$ & $\begin{array}{l}.2 \\
67 \\
(* \\
*) \\
\end{array}$ & $\begin{array}{l}.4 \\
35 \\
(* \\
*) \\
\end{array}$ & $\begin{array}{l}.4 \\
46 \\
(* \\
*) \\
\end{array}$ & $\begin{array}{l}.6 \\
60 \\
(* \\
*) \\
\end{array}$ & $\begin{array}{l}.5 \\
87 \\
(* \\
*) \\
\end{array}$ & 1 & \\
\hline 11 & $\begin{array}{l}.2 \\
29 \\
(* \\
*) \\
\end{array}$ & $\begin{array}{l}.2 \\
90 \\
(* \\
*) \\
\end{array}$ & $\begin{array}{l}.2 \\
45 \\
(* \\
*) \\
\end{array}$ & $\begin{array}{l}.3 \\
41 \\
(* \\
*) \\
\end{array}$ & $\begin{array}{l}3 \\
18 \\
(* \\
*) \\
\end{array}$ & $\begin{array}{l}.3 \\
67 \\
(* \\
*) \\
\end{array}$ & $\begin{array}{l}4 \\
03 \\
(* \\
*) \\
\end{array}$ & $\begin{array}{l}.3 \\
64 \\
(* \\
*) \\
\end{array}$ & $\begin{array}{l}.1 \\
86 \\
(* \\
*)\end{array}$ & $\begin{array}{l}.2 \\
36 \\
(* \\
*) \\
\end{array}$ & 1 \\
\hline
\end{tabular}

1. Autonomy Support (AS), 2. Competence Support (CS), 3. Relatedness Support (RS), 4. Autonomy, 5. Competence, 6. Relatedness, 7. Intrinsic motivation, 8. Identified regulation, 9. Introjected regulation, 10. External regulation, 11. Amotivation 
TABLE IV.

REGRESSION WEIGHTS

\begin{tabular}{|c|l|l|l|l|l|l|}
\hline & & & Estimate & \multicolumn{1}{|c|}{ S.E. } & $\boldsymbol{C} . \boldsymbol{R}$. & $\boldsymbol{P}$ \\
\hline 4 & & 1 & 0.186 & 0.02 & 7.708 & $* * *$ \\
\hline 4 & & 2 & 0.186 & 0.039 & 20.484 & $* * *$ \\
\hline 4 & & 3 & 0.164 & 0.02 & 6.841 & $* * *$ \\
\hline 5 & & 1 & 0.314 & 0.026 & 9.303 & $* * *$ \\
\hline 5 & & 2 & 0.646 & 0.041 & 14.082 & $* * *$ \\
\hline 5 & & 3 & 0.258 & 0.025 & 7.985 & $* * *$ \\
\hline 6 & & 1 & 0.191 & 0.017 & 8.284 & $* * *$ \\
\hline 6 & & 2 & 0.875 & 0.037 & 19.922 & $* * *$ \\
\hline 6 & & 3 & 0.1567 & 0.017 & 6.891 & $* * *$ \\
\hline 7 & & 4 & -0.561 & 0.149 & -4.509 & $* * *$ \\
\hline 8 & & 4 & -2.329 & 0.249 & -8.883 & $* * *$ \\
\hline 9 & & 4 & -2.467 & 0.254 & -9.221 & $* * *$ \\
\hline 10 & & 4 & -2.145 & 0.232 & -8.87 & $* * *$ \\
\hline 11 & & 4 & -0.423 & 0.153 & -3.472 & $* * *$ \\
\hline 7 & & 5 & -0.261 & 0.078 & -4.291 & $* * *$ \\
\hline 8 & & 5 & -0.023 & 0.072 & -0.323 & 0.747 \\
\hline 9 & & 5 & 0.268 & 0.087 & 3.121 & 0.002 \\
\hline 10 & & 5 & 0.046 & 0.077 & 0.605 & 0.545 \\
\hline 11 & & 5 & -0.026 & 0.084 & -0.413 & 0.68 \\
\hline 7 & & 6 & 1.298 & 0.177 & 9.886 & $* * *$ \\
\hline 8 & & 6 & 2.798 & 0.285 & 10.43 & $* * *$ \\
\hline 9 & & 6 & 2.634 & 0.287 & 9.783 & $* * *$ \\
\hline 10 & & 6 & 2.393 & 0.263 & 9.753 & $* * *$ \\
\hline 11 & & 6 & 0.889 & 0.177 & 7.067 & $* * *$ \\
\hline & & & & & & \\
\hline
\end{tabular}

Autonomy Support (AS), 2. Competence Support (CS), 3. Relatedness Support (RS), 4. Autonomy. 5. Competence, 6. Relatedness, 7. Intrinsic motivation, 8. Identified regulation, 9. Introjected regulation, 10. External regulation, 11. Amotivation

model's validity. Structural equation analysis found through the calculated path coefficient revealed that relations among motivation strategies, psychological needs, and motivation groups existed across all channels except influence of competence on identified regulation and external regulation. Amotivation results were significant, with a level of 0.05 or lower.

\section{Results}

The analysis results verified the research hypothesis. Analysis of the relations based on the regression weights in Table 4 was used to calculate the standardized figures shown in Figure 11. This indicates that perceived relatedness and competence among the three psychological needs positively influenced each type of motivation. The need for relatedness in addition to competence is significant since it has been studied in the past, and indicates that relatedness to others is important in an e-learning environment, where learning mainly occurs in isolation. In contrast, the value of autonomy->intrinsic is -0.561 and displays increased autonomy when compared to intrinsic motivation. Moreover, like other motivations, autonomy displays a negative influence because of a close causal relation between autonomy and competence, in addition to autonomy and relatedness.

\section{DISCUSSION AND CONCLUSION}

Conclusions obtained from the findings of this study are as follows

First, this study proved that motivation strategies are effective when applied to e-learning systems. Thus, the variety of motivation strategies applied in this research could aid the development of other e-learning systems and increase students' intrinsic motivation.

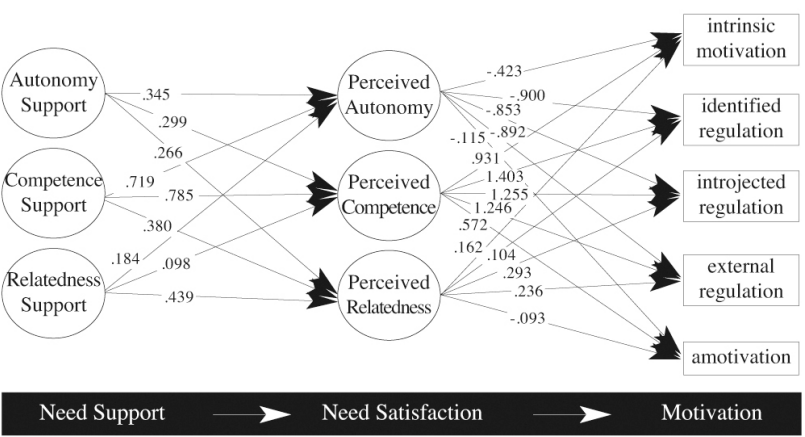

Figure 11. Research Model Result

Second, SDT, a motivation theory that has usually been applied in traditional classrooms, appears to be effective in an e-learning environment as well. This implies that various education models using SDT can be applied in elearning environments and private institutes.

Third, the need for competence in e-learning is the most important factor in increasing intrinsic motivation. Moreover, the need for relatedness is also significant, and such findings imply that learners value social interaction, even in typically isolated e-learning environments.

However, one should interpret the results obtained from this study carefully. Despite verifying that motivation is a result of on-going educational intervention, it does not definitively prove a causal relation. Furthermore, the three psychological needs applied in this study apply to all individuals regardless of their specialization or societal position. Hence, additional factors should be investigated to increase student motivation and its positive influence on English language learning.

Finally, the findings of this study may not be applicable to middle, high school, college students, or ESL learners as it targeted Korean grade schoolers. Despite such limitations, however, this study is significant since it establishes a theory-based e-learning system, and includes an empirical study of motivation theories ordinarily applied in traditional classrooms to an e-learning environment through educational practice.

\section{REFERENCES}

[1] Carr, Sarah. 2000. "As distance education comes of age, the challenge is keeping the Students," The Chronicle of higher Education, vol.46, pp39-41, Feb.

[2] Chen, K. C. and Jang, S. J. 2011. "Motivation in online learning: Testing a model of self-determination theory," Computers in $\mathrm{Hu}$ man Behavior 27(3): 1043-1284.

[3] Deci, E. L. 1975. "Cognitive evaluation theory and some comments on the Calder and Staw critique," Journal of Personality and Social Psychology," vol. 31(1), pp. 81-85, Jan. http://dx.doi.org/10.1037/h0076168

[4] Deci, E. L. and Ryan, R. M. 1980. "The empirical exploration of intrinsic motivational processes," Advances in experimental social psychology, vol.13. $\quad$ http://dx.doi.org/10.1016/S00652601(08)60130-6

[5] Deci, E. L. and Ryan, R. M. 1985. "Self-Determination" Wiley.

[6] Deci, E. L. and Ryan, R. M. 2000. "Self-determination theory and the facilitation of intrinsic motivation, social development, and well-being," American Psychologist, vol. 55(1), pp. 68-78, Jan. http://dx.doi.org/10.1037/0003-066X.55.1.68

[7] Deci, E. L., Koestner, R. and Ryan, R. M. 2001. "Extrinsic rewards and intrinsic motivation in education: Reconsidered once again," Review of Educational Research, vol. 71, pp. 1-27. http://dx.doi.org/10.3102/00346543071001001 
[8] Dörnyei. 1994. "Motivation and Motivating in the Foreign Language Classroom," The Modern Language Journal, vol. 78(3), pp. 273-284. http://dx.doi.org/10.1111/j.1540-4781.1994.tb02042.x

[9] Hasegawa Sinobu. 2006. Adaptive navigation planning navigation path hyperspace self-directed learning," The Japanese Society for Artificial Intelligence, vol. 21, pp. 406-416. http://dx.doi.org/10.1527/tjsai.21.406

[10] Hiromori, T. 2006. "The effects of educational intervention on L2 learners' motivational development," JACET Bulletin vol. 43, pp. $1-14$.

[11] Noels, K. A. Pelletier, L., Clément, R. and Vallerand, R., 2000. "Why are you learning a second language? Motivational orientations and Self-determination Theory," Language Learning, vol. 50, pp. 57-85. http://dx.doi.org/10.1111/0023-8333.00111

[12] Noels, K. A. 2001. "Learning Spanish as a second language: Learners' orientations and perceptions of their teachers' communication style," Language Learning, vol. 51, pp. 107-144. http://dx.doi.org/10.1111/0023-8333.00149

[13] White, RW. 1959. "Motivation reconsidered: the concept of competence," Psychological review, Vol 66(5), pp. 297-333, Sep. http://dx.doi.org/10.1037/h0040934

[14] Ryan, R. M. and Deci, E. L. 2000. "Self-determination Theory and the facilitation of intrinsic motivation, social development and well-being," American Psychologist, vol. 55, pp. 68-78. http://dx.doi.org/10.1037/0003-066X.55.1.68

[15] Vallerand. 1992. "The Academic Motivation Scale: A Measure of Intrinsic, Extrinsic, and Amotivation in Education," Educational and Psychological Measurement, WINTER vol. 52 no. 4 10031017.

\section{APPENDIX}

\section{Assessment of the Three Psychological Needs}

\section{Autonomy}

$\ominus$ English Buddy gives us freedom of choice to a certain degree in terms of textbooks, classes, and learning contents

$\ominus$ English Buddy enables me to study without burden

$\circledast$ English Buddy enables me to study as much as I want

\section{Competence}

$\ominus$ English Buddy allows teachers to evaluate and compliment me

$\ominus$ English Buddy makes me work hard

$\circledast$ English Buddy will improve my English skills if I work hard

(4) English Buddy gives me the satisfaction of doing well

\section{Relatedness}

$\ominus$ With English Buddy, there is an atmosphere of cooperation

$\ominus$ I am good friends with my fellow English Buddy students $\circledast$ I have made close friends through the English Buddy classes

(4) English Buddy classes have a warm and pleasant atmosphere

Assessment of Intrinsic Motivation in English Studies

$\Theta$ Studying English is fun

$\ominus$ It is exciting to discover new things while studying English

$\circledast$ It is fun to increase my knowledge of English

(4) English classes are fun

Identified Regulation

$\ominus$ I want to have English skills for future use

$\ominus$ Learning English is necessary for me

$\circledast$ I want to speak at least one foreign language

(4) Learning English helps me improve myself

Introjected Regulation

$\ominus$ I think I will be regretful if I do not study English now

$\ominus$ Speaking English well seems cool

$\circledast$ Speaking English is a common thing

External Regulation

$\ominus$ I want to get good grades

$\ominus$ Studying English is a part of school

$\circledast$ Society forces us to study English

\section{Amotivation}

$\ominus$ I do not know what I am obtaining from English classes

$\ominus$ I do not think studying improves my English

$\circledast$ I have no intention of identifying a reason to study English

(4) Studying English seems like a waste of time

\section{AUTHORS}

Mi-hyang Bang is ph. D. with the Graduate School Culture Technology of Kaist., Daejeon, Korea, 305-701(email: carrotseed@nate.com).

KwangYun Wohn is a professor with the Graduate School Culture Technology of Kaist., Daejeon, Korea, 305-701 (e-mail: wohn@kaist.ac.kr).

Chungkon Shi is a professor with the Graduate School Culture Technology of Kaist., Daejeon, Korea, 305-701 (e-mail: chungkon@kaist.ac.kr)

Submitted 25 March 2014. Published as resubmitted by the authors 14 June 2014. 